\title{
Autotrophic Growth of Paracoccus denitrificans in Aerobic Condition and the Accumulation of Biodegradable Plastics from $\mathrm{CO}_{2}$
}

\author{
Kenji Tanaka ${ }^{1, *}$, Shunya Mori $^{1}$, Mai Hirata ${ }^{1}$, Hiromi Matsusaki ${ }^{2}$ \\ ${ }^{1}$ Department of Biological and Environmental Chemistry, Faculty of Humanity-Oriented Science and Engineering, Kindai University, \\ Japan \\ ${ }^{2}$ Department of Food and Health Sciences, Faculty of Environmental and Symbiotic Sciences, Prefectural University of Kumamoto, \\ Japan
}

Copyright $\subseteq 2016$ by authors, all rights reserved. Authors agree that this article remains permanently open access under the terms of the Creative Commons Attribution License 4.0 International License

\begin{abstract}
The cell growth on $\mathrm{H}_{2}$ and $\mathrm{O}_{2}$ as the energy source and $\mathrm{CO}_{2}$ as the sole carbon source in the autotrophic culture condition was tested for the gram-negative bacteria Paracoccus spp. The aerobic growth in the autotrophic condition was only observed in Paracoccus denitrificans NBRC13301 and P.pantotrophus NBRC102493. Both strains were sensitive to $\mathrm{O}_{2}$ in particular the growth of P.pantotrophus was completely inhibited at the concentrations above $2 \% \mathrm{O}_{2}$. P.denitrificans grew until $15 \% \mathrm{O}_{2}$ however the optimum $\mathrm{O}_{2}$ concentration was $5 \%$. The growth characteristic of P.denitrificans was investigated by $\mathrm{pH}$-controlled batch culture with supplying the gas mixture of $\mathrm{H}_{2}, \mathrm{O}_{2}$ and $\mathrm{CO}_{2}$. The specific growth rate was $0.12 \mathrm{~h}^{-1}$ at $5 \% \mathrm{O}_{2}, 30^{\circ} \mathrm{C}$ and $\mathrm{pH} 7.0$. The growth was much slower than other hydrogen-oxidizing bacteria however P.denitrificans accumulated biodegradable plastic, polyhydroxybutyrate, PHB with the content of $57.3 \% \mathrm{w} / \mathrm{w}$ in the cell under nitrogen limitation. Under DO limitation, the cell concentration increased to $25 \mathrm{~g} / \mathrm{L}$ without accumulating $\mathrm{PHB}$ if $\mathrm{NH}_{3}$ solution as the nitrogen source was fed sufficiently.
\end{abstract}

Keywords Polyhydroxyalkanoates, Paracoccus, Hydrogen-oxidizing Bacterium

\section{Background}

Paracoccus spp. is the gram-negative bacteria possessing the ability for denitrification (reduction of $\mathrm{NO}_{3}^{-}$to $\mathrm{N}_{2}$ ). They play an important role in the nature. Especially, P.denitrificans is employed in the biotreatment of waste water. Genome of this bacterium was sequenced in 2004 [1]. Paracoccus spp. accumulates poly- $\beta$-hydroxybutyrate (PHB) or the copolyester of $\beta$-hydroxybutyrate and other hydroxyalkanoate (PHA) in their cells and the polyester is expected as biodegradable plastics [2]. Some strains of Paracoccus spp. grow with $\mathrm{CO}_{2}$ as carbon source, and $\mathrm{H}_{2}$ or thiosulfate as energy source in autotrophic condition. Many researchers have been reported about Paracoccus spp., however in most of the researches for the autotrophic culture using the inorganic gasses as the substrate was studied only for denitrification in anaerobic condition, and the accumulation of PHB or PHAs was studied only in heterotrophic culture using organic compounds as the substrate, for example feeding mixed substrate of acetic acid and valeric acid [3], glycerol [4], methanol and $n$-amyl alcohol [5]. We studied the growth characteristics of Paracoccus spp. in the autotrophic condition using the gas mixture of $\mathrm{H}_{2}, \mathrm{O}_{2}$ and $\mathrm{CO}_{2}$ as the substrate, and high cell density culture and the accumulation of PHB from $\mathrm{CO}_{2}$.

\section{Methods}

The bacteria used in this study were Paracoccus denitrificans NBRC13301, P.alcaliphilus JCM7364 ${ }^{\mathrm{T}}$, P.pantotrophus NBRC102493, P.thiocyanatus NBRC14569, P.aminophilus NBRC16710, P.aminovorans NBRC 16711 and P.versutas NBRC14567. All the strains were purchased from NBRC (NITE Biological Resource Center, National Institute of Technology and Evaluation, Tokyo) or JCM (Japan Collection of Microorganisms, RIKEN, Tsukuba, Japan). These bacteria were subcultured every three weeks on BY medium or PYG medium agar plates. The composition of $\mathrm{BY}$ media was meat extract $5.0 \mathrm{~g}$, peptone $5.0 \mathrm{~g}, \mathrm{NaCl} 2.5 \mathrm{~g}, \mathrm{~K}_{2} \mathrm{HPO}_{4} 0.1 \mathrm{~g}, \mathrm{MgSO}_{4} \cdot 7 \mathrm{H}_{2} \mathrm{O} 0.2 \mathrm{~g}$, yeast extract $5.0 \mathrm{~g}$ and agar $15 \mathrm{~g}$ per $1 \mathrm{~L}$ of distilled water $(\mathrm{pH} 7.2)$; and that of PYG medium was peptone $5.0 \mathrm{~g}$, yeast extract $5.0 \mathrm{~g}$ and glucose $5.0 \mathrm{~g}$ per $1 \mathrm{~L}(\mathrm{pH} 7.0)$.

Basic composition of mineral medium for autotrophic 
culture was $\left(\mathrm{NH}_{4}\right)_{2} \mathrm{SO}_{4} 3.0 \mathrm{~g}, \mathrm{KH}_{2} \mathrm{PO}_{4} 4.0 \mathrm{~g}, \mathrm{NaHPO}_{4} 0.8 \mathrm{~g}$, $\mathrm{NaHCO}_{3} 1.0 \mathrm{~g}, \mathrm{MgSO}_{4} \cdot 7 \mathrm{H}_{2} \mathrm{O} 0.2 \mathrm{~g}$ and $1 \mathrm{~L}$ distilled water. The $\mathrm{pH}$ was adjusted to 7.0 with $1 \mathrm{M} \mathrm{NaOH}$ then it was autoclaved $20 \mathrm{~min}$ at $120^{\circ} \mathrm{C}(\mathrm{Mg}$ salt was autoclaved separate from other salts). After cooling, $0.1 \mathrm{~mL}$ of filter-sterilized trace elements solution was added to the medium. Composition of the trace elements solution was $\mathrm{CoCl}_{2} 119 \mathrm{mg}, \mathrm{FeSO}_{4} \cdot 7 \mathrm{H}_{2} \mathrm{O} 16.2 \mathrm{~g}, \mathrm{NiCl}_{2} \cdot 6 \mathrm{H}_{2} \mathrm{O} 118 \mathrm{mg}$, $\mathrm{CrCl}_{2} \cdot 6 \mathrm{H}_{2} \mathrm{O} 133 \mathrm{mg}, \mathrm{CuSO}_{4} \cdot 5 \mathrm{H}_{2} \mathrm{O} 156 \mathrm{mg}, \mathrm{CaCl}_{2} \cdot 2 \mathrm{H}_{2} \mathrm{O}$ $10.3 \mathrm{~g}$ and citric acid $15.6 \mathrm{~g}$ in $100 \mathrm{~mL}$ of $1 \mathrm{M} \mathrm{HCl}$, which was originally used for a hydrogen-oxidizing bacterium, Ralstonia eutropha [6].

Autotrophic culture experiment was carried out carefully using the explosive gas mixture of $\mathrm{H}_{2}, \mathrm{O}_{2}$ and $\mathrm{CO}_{2}$ as described below [7]. The bacteria were refreshed on the $\mathrm{BY}$ or PYG agar plate, and further inoculated into $20 \mathrm{~mL}$ of the mineral liquid medium in 300-mL Erlenmeyer flask. The flask was plugged with a rubber stopper which was inserted with a glass tube connected to a silicone tube and a sterile membrane filter (pore size, $0.2 \mu \mathrm{m}$ ). The inside of the flask was vacuumed and then it was filled with $\mathrm{H}_{2}, \mathrm{O}_{2}$ and $\mathrm{CO}_{2}$ from each gas cylinder. Basic composition of the substrate gas mixture was $\mathrm{H}_{2} 80 \%, \mathrm{O}_{2} \quad 10 \%$, and $\mathrm{CO}_{2} 10 \%$. Cultivation was carried at a temperature of $30^{\circ} \mathrm{C}$ and a reciprocal shaking of $200 \mathrm{rpm}$. High cell density culture experiment was carried out using a glass jar fermenter (total volume $1000 \mathrm{~mL}$; working volume $600 \mathrm{~mL}$ ) equipped with a pH controller, PHC-2201 and a dissolved oxygen (DO) meter, DJ-1033 (Biott Co., Ltd., Tokyo). Batch culture was performed with a recycled-gas closed-circuit culture system. The substrate gas mixture in the gas chamber was supplied to the fermenter at a flow rate of $0.5 \mathrm{vvm}$ and the exhausted from the fermenter was returned to the chamber. The agitation speed was kept at $1200 \mathrm{rpm}$. As the cell concentration increases, the foaming of culture liquid becomes vigorous and it causes the flow out of culture liquid from the fermenter. Then, a defoaming agent (Einol, Biott Co. Ltd., Tokyo) was used in high cell density culture.

Cell growth was monitored by measuring turbidity $\left(\mathrm{OD}_{600 \mathrm{~nm}}\right)$ of the culture liquid. The composition of the substrate gas mixture in the flask and the fermentation system was measured by a gas chromatograph (Shimadzu type GC-8A) using a column $4 \mathrm{~mm} \times 6 \mathrm{~m}$ into which a molecular sieve $5 \mathrm{~A}$ and a Porapack $\mathrm{Q}$ were packed. Total ammonia $\left(\mathrm{NH}_{4}-\mathrm{N}\right)$ in culture liquid was determined by indophenol blue reaction. PHB accumulated in the cells was determined according to the method using gas chromatography [8]. The lyophilized cells, a mixture of 2 $\mathrm{mL}$ of methanol acidified with $3 \%(\mathrm{w} / \mathrm{v}) \mathrm{H}_{2} \mathrm{SO}_{4}$ and $2 \mathrm{~mL}$ of chloroform were added into a screw cap vial then it was heated at $100^{\circ} \mathrm{C}$ for $3.5 \mathrm{~h}$ for degradation of PHB, and esterification of hydroxybutyric acid and methanol. After cooling, $1 \mathrm{~mL}$ of $\mathrm{H}_{2} \mathrm{O}$ was added into the vial then the suspension was shaken well for $10 \mathrm{~min}$. After two phases were allowed to separate, the organic phase containing the methyl ester was applied to gas chromatography.

\section{Results}

\subsection{Growth of Paracoccus Strains}

Growth of Paracoccus spp. in the autotrophic condition was tested by flask culture. The head space inside the culture flask was filed with the gas mixture with a ratio $\mathrm{H}_{2} / \mathrm{O}_{2} / \mathrm{CO}_{2}=8: 1: 1$ before the start of cultivation. After 7 days cultivation, the increase in the turbidity of culture liquid and the consumption of substrate gas (a decrease in pressure of head space gas inside the flask) were observed only in P.denitrificans NBRC13301. There was no growth in the other Paracoccus spp. It is known that many strains of hydrogen-oxidizing bacteria are sensitive to $\mathrm{O}_{2}$ although they are aerobic bacteria. Then, the culture test was carried out again with lowering $\mathrm{O}_{2}$ concentration in the substrate gas mixture (Table). The cell growth was observed in P.denitrificans NBRC13301 and P.pantotrophus NBRC102493. P.denitrificans grew from 5 to $15 \% \mathrm{O}_{2}$ and P.pantotrophus did only at $2 \% \mathrm{O}_{2}$.

Table 1. Growth of Paracoccus spp. at various concentrations of $\mathrm{O}_{2}$ in autotrophic culture condition. The increase in cell growth $\left(\mathrm{OD}_{600}\right)$ after 48 $\mathrm{h}$ from the inoculation was compared $(n=2)$.

\begin{tabular}{ccccccc}
\hline \multirow{2}{*}{ Species } & \multicolumn{6}{c}{$\mathrm{O}_{2}$ concentration (\%) in substrate gas mixture } \\
\cline { 2 - 7 } & 0 & 2 & 5 & 10 & 15 & 20 \\
\hline $\begin{array}{c}P . \text { denitrificans } \\
\text { NBRC13301 }\end{array}$ & 0 & 1.21 & 4.85 & 3.89 & 2.93 & 0 \\
$\begin{array}{c}P . \text { alcaliphilus } \\
\text { JCM7364 }\end{array}$ & 0 & 0 & 0 & 0 & 0 & 0 \\
$\begin{array}{c}P \text { pantotrophus } \\
\text { NBRC102493 }\end{array}$ & 0 & 1.19 & 0 & 0 & 0 & 0 \\
$\begin{array}{c}P . \text { thiocyanatus } \\
\text { NBRC14569 }\end{array}$ & 0 & 0 & 0 & 0 & 0 & 0 \\
$\begin{array}{c}P . \text { aminophilus } \\
\text { NBRC16710 }\end{array}$ & 0 & 0 & 0 & 0 & 0 & 0 \\
$\begin{array}{c}P . \text { aminovorans } \\
\text { NBRC 16711 } \\
P . \text { versutas }\end{array}$ & 0 & 0 & 0 & 0 & 0 & 0 \\
NBRC14567 & 0 & 0 & 0 & 0 & 0 & 0 \\
\hline
\end{tabular}

These two strains, in particular P.pantotrophus was much more sensitive to $\mathrm{O}_{2}$ than other hydrogen-oxidizing bacterium like Ralstonia eutropha and Alcaligenes latus, Ideonella dechloratans [9] and A.hydrogenophilus [10].

\subsection{Growth Condition for P.dentrificans}

P.denitrificans NBRC13301 showed the best growth among the Paracoccus spp. in the autotrophic condition. Hence, the growth characteristics of P.denitrificans were investigated in detail. As a result, optimum temperature and $\mathrm{pH}$ were $30^{\circ} \mathrm{C}$ and $\mathrm{pH} 7.0$, respectively. Among the nitrogen sources of nitrate, ammonium salts and urea, the best growth was obtained with $\left(\mathrm{NH}_{4}\right)_{2} \mathrm{SO}_{4}$. There was no growth with urea (the data are not shown). Figure 1 shows a fermentation time course of P.denitrificans NBRC13301 in flask culture. 


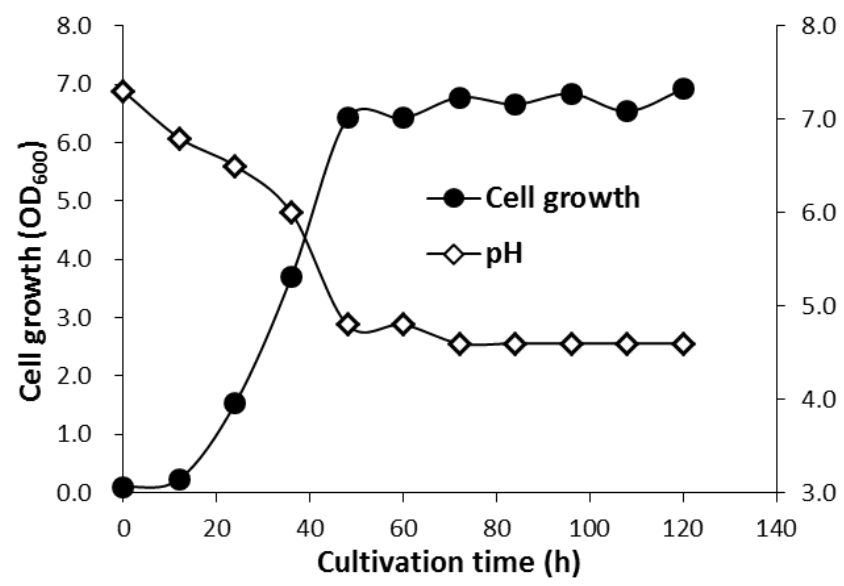

Figure 1. Time course for flask culture of $P$. denitrificans NBRC13301 in autotrophic condition using the substrate gas mixture with the ratio of $\mathrm{H}_{2} / \mathrm{O}_{2} / \mathrm{CO}_{2}=85: 5: 10$.

The head space substrate gas in the flask was refiled several times during the cultivation however the cell concentration was not over 8.0 in $\mathrm{OD}_{600}$ with any medium composition. The $\mathrm{OD}_{600}=8.0$ was almost equivalent to about $3.2 \mathrm{~g} / \mathrm{L}$ of dry cell weight. It was considered that the cell growth was inhibited by the decrease in $\mathrm{pH}$ of culture liquid.

\subsection{High Cell Density Culture of P.dentrificans and PHB Accumulation from $\mathrm{CO}_{2}$}

High cell density culture of P.denitrificans NBRC13301 was examined using a pH-controller and a glass jar fermenter. The recycled-gas closed-circuit culture system was used because the high performance of gas utilization. The $\mathrm{pH}$ of culture liquid in the fermenter was maintained around $7.0 \pm 0.2$ by feeding $4 \% \mathrm{w} / \mathrm{v} \mathrm{NH}$ solution or $1 \mathrm{M}$ $\mathrm{NaOH}$ automatically. Cell concentration was determined by measuring $\mathrm{OD}_{600}$ of the culture liquid and dry weight of the centrifuged cells. The substrate gas mixture was supplied into the culture medium from a gas chamber (total volume, ca.15 L) using an airtight air pump. The exhausted gas from the fermenter was returned to the gas chamber for reuse. The inner pressure of the gas chamber was maintained at almost constant level because saturated saline water was voluntarily introduced according to the decrease in the volume of substrate gas mixture [7]. Figure 2 (a) shows the fermentation time course of the strain NBRC13301 at pH7.0 with feeding $4 \% \mathrm{w} / \mathrm{v} \mathrm{NH}_{3}$ solution. Cultivation was started by recycling the substrate gas with the volume ratio of $\mathrm{H}_{2} / \mathrm{O}_{2} / \mathrm{CO}_{2}=85: 5: 10$ within the culture system. As the fermentation proceeds, the gas composition in the culture system changed, especially $\mathrm{O}_{2}$ concentration sharply decreased, the gas mixture in the chamber was exchanged several times to reset to the initial composition. The cells multiplied at the specific growth rate of approximately 0.12 $\mathrm{h}^{-1}$ during the exponential growth phase. After $42 \mathrm{~h}$ from the start of cultivation, DO decreased to almost 0ppm (the data is not shown), the exponential growth ceased, then the cell concentration increased almost linearly with the time. When the amount of cells increased to the dry weight concentration of $8.12 \mathrm{~g} / \mathrm{L}$ after $120 \mathrm{~h}$, we stopped the cultivation because it was too difficult to maintain $\mathrm{O}_{2}$ concentration of gas phase in the culture system at $5 \%$. The cell concentration increased to about 2.5 times as that of the flask culture. Accumulation of PHB in the cells was slight throughout the cultivation when feeding $4 \%$ w/v $\mathrm{NH}_{3}$ solution. The culture liquid at the end of cultivation contained sufficient amount of $\mathrm{NH}_{4}{ }^{+}$and $\mathrm{PO}_{4}{ }^{3-}$ for vigorous multiplication of the cell. Figure 2(b) shows the fermentation time course with feeding $1 \mathrm{M} \mathrm{NaOH}$ instead of $\mathrm{NH}_{3}$ solution for $\mathrm{pH}$ control. When $\mathrm{NH}_{4}^{+}$was exhausted after $45 \mathrm{~h}$, the cells began to accumulate PHB. The PHB content of the cells increased to $57.3 \% \mathrm{w} / \mathrm{w}$ at the end of cultivation. It is known that PHB generally accumulates in nitrogen- or DO-limited culture condition. Our results indicate that in case of P.denitrificans, PHB accumulation is not stimulated under DO limitation but nitrogen limitation.
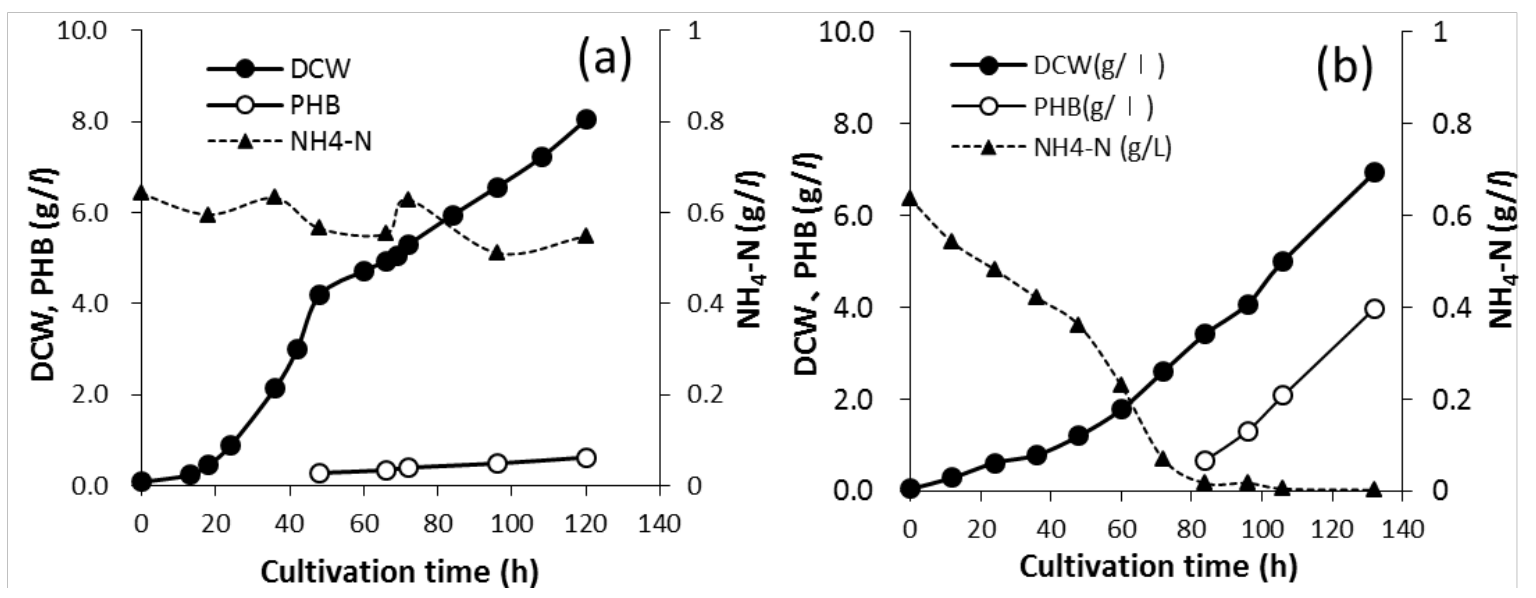

Figure 2. Time course for pH-controlled autotrophic culture of P.denitrificans NBRC13301 using jar fermenter and recycled-gas closed-circuit culture system. $\mathrm{pH}$ was controlled during the cultivation by feeding $4 \% \mathrm{NH}_{3}$ solution (a) and $1 \mathrm{MNaOH}$ (b) 
Figure 3 shows the fermentation time course with exchanging the substrate gas mixture in the gas chamber every $12 \mathrm{~h}$ during cultivation. The $\mathrm{pH}$ was controlled by feeding $4 \% \mathrm{w} / \mathrm{v} \mathrm{NH}_{3}$ solution. The gas mixture with the volume ratio of $\mathrm{H}_{2} / \mathrm{O}_{2} / \mathrm{CO}_{2}=85: 5: 10$ was used from the start of cultivation until $50 \mathrm{~h}$, then the ratio was changed to $\mathrm{H}_{2} / \mathrm{O}_{2} / \mathrm{CO}_{2}=80: 10: 10$. After $80 \mathrm{~h}$, the volume ratio of the newly prepared gas mixture was changed to $\mathrm{H}_{2} / \mathrm{O}_{2} / \mathrm{CO}_{2}=$ 75:15:10 and the ratio was used until the end. As a result, DO was almost kept at 0ppm after $40 \mathrm{~h}$ (the data is not shown) however the cells continued to increase for the long DO limitation. When the cell concentration increased to about $25 \mathrm{~g} / \mathrm{L}$ after $140 \mathrm{~h}$, we stopped the cultivation because foaming of the culture liquid was so vigorous that we could not prevent the culture liquid from flowing out of the fermenter. The PHB accumulation was very small because the nitrogen source in the culture liquid was sufficient throughout the cultivation by feeding $\mathrm{NH}_{3}$ solution.

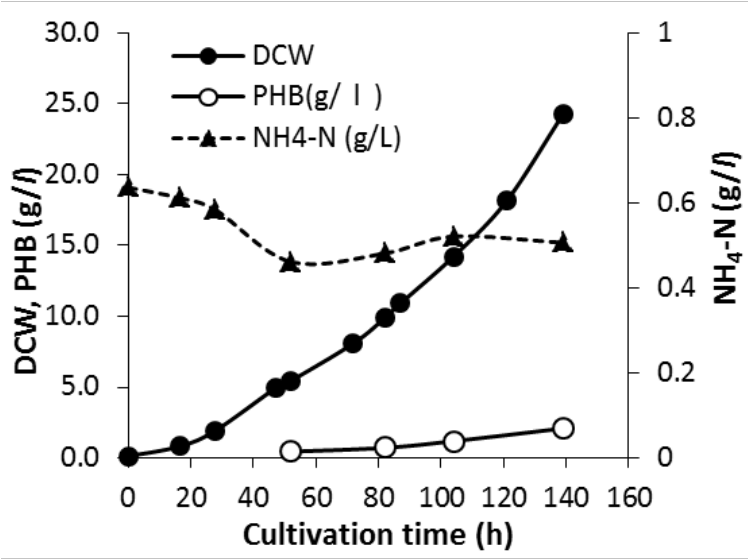

Figure 3. Time course for $\mathrm{pH}$-controlled autotrophic culture of P.denitrificans NBRC13301 using jar fermenter and recycled-gas closed-circuit culture system. The $\mathrm{O}_{2}$ concentration in the substrate gas mixture was raised from $5 \%$ at the start to $10 \%$ after $50 \mathrm{~h}$ then to $15 \%$ after 80h. $\mathrm{pH}$ was controlled during the cultivation by the feeding $4 \% \mathrm{NH}_{3}$ solution.

\subsection{Discussion}

Our research showed that among the 7 strains of Paracoccus spp. tested, P.denitrificans NBRC13301 and P.pantotrophus NBRC102493 grow in the autotrophic culture condition using the gas mixture of $\mathrm{H}_{2}, \mathrm{O}_{2}$ and $\mathrm{CO}_{2}$ as the substrate. However, both strains were very sensitive to $\mathrm{O}_{2}$ especially P.pantotrophus did not grow with the gas mixture containing $\mathrm{O}_{2}$ above $2 \%$. On the other hand, P.denitrificans grew at $\mathrm{O}_{2}$ concentrations up to $15 \%$ and the optimum $\mathrm{O}_{2}$ concentration for the cell growth was $5 \%$. The specific growth rate of P.denitrificans in the autotrophic condition was $0.12 \quad \mathrm{~h}^{-1}$ at $5 \% \quad \mathrm{O}_{2}$. The growth of P.denitrificans was much slower than other hydrogen-oxidizing bacteria, R.eutropha, A.latus, I.dechloratans [9] and A.hydrogenophilus [10]. The specific growth rate of R.eutropha at $5 \% \mathrm{O}_{2}$ was $0.42 \mathrm{~h}^{-1}$ [7]. It is reported that in case of R.eutropha (A.eutrophus), the soluble $\mathrm{NAD}^{+}$-reducing hydrogenase was inactivated by $\mathrm{O}_{2}$ when $\mathrm{H}_{2}$ is available as electron donor [11].

PHB and the copolyester of D-3-hydroxybutric acid and other hydroxyalkanoic acid, PHA are expected as the biodegradable "Green plastics". However, most of the researches for microbial production of PHAs are investigated on organic acids, fatty acid and plant oil as the substrate, especially by using recombinants of R.eutropha or Escherichia coli with improved the intracellular content and the monomer composition of polyester in recent years [12-15]. Biosynthesis of copolymer from "unrelated carbon source" like glucose is also studied using engineered strains [16-22]. There are only several researches reported for the autotrophic production from $\mathrm{CO}_{2}$ [23]. We have been studied the production of $\mathrm{PHB}$ from $\mathrm{CO}_{2}$ employing several strains of hydrogen-oxidizing bacteria [9, 24-27]. In our study, $60 \mathrm{~g} / \mathrm{L}$ of the cells with $36 \mathrm{~g} / \mathrm{L}$ of PHB were obtained in autotrophic culture of R.eutropha with the conventional type jar fermenter in $60 \mathrm{~h}$ [24]. Furthermore, the use of a basket-type agitator with very high performance for oxygen transfer $\left(k_{\mathrm{L}} \mathrm{a}, 2970 \mathrm{~h}^{-1}\right)$ enabled to produce $91.3 \mathrm{~g} / \mathrm{L}$ of the cells with $61.9 \mathrm{~g} / \mathrm{L}$ of PHB in $40 \mathrm{~h}$ in spite of supplying the substrate gas mixture with the lower $\mathrm{O}_{2}$ concentration below the "lower explosion limit" was supplied [25]. PHB can be produced from $\mathrm{CO}_{2}$ even in the presence of high concentration of carbon monoxide (CO) by employing the $\mathrm{CO}$ tolerant hydrogen-oxidizing bacterium Ideonella sp.O-1 that we isolated [9]. Volova et al. also reported the production of a copolymer containing $\beta$-hydroxybutyrate more than $99 \mathrm{~mol} \%$ from $\mathrm{CO}_{2}$ in model gas mixture containing CO by employing R.eutropha B5786 [28].

In this study, it was shown that the cell growth of P.denitrificans in autotrophic condition is more sensitive to $\mathrm{O}_{2}$ and slower than other hydrogen-oxidizing bacteria. However, PHB accumulated in the cells with the content of $57.3 \% \mathrm{w} / \mathrm{w}$ under nitrogen limitation while it did not under DO limitation. In the practical fermentation process for the production of PHB employing hydrogen-oxidizing bacteria in commercial scale, $\mathrm{O}_{2}$ concentration of the substrate gas mixture must be maintained lower than $6.9 \%$ to prevent the explosion of $\mathrm{H}_{2}$ [25]. The condition does not exclude P.denitrificans from the candidate strains for PHB producer. It will be possible to achieve high PHB yield from $\mathrm{CO}_{2}$ employing P.denitrificans if the fermenter like the basket-type agitator to give high performance for oxygen transfer. On the other hand, some strains of this species are already used for the commercial production other useful substances for instance vitamin $\mathrm{B}_{12}$ (cyanocobalamin) from methanol. The ability of P.denitrificans to continue the cell growth without PHB accumulation under DO limitation will be beneficial for production of commercially useful substances except PHAs from $\mathrm{CO}_{2}$.

\section{REFERENCES}


[1] KEGG (Kyoto Encyclopedia of Genes and Genomes). Paracoccus denitrificans: Genome information. Available at: http://www.genome.jp/kegg-bin/show_ organism?org $=\mathrm{T} 00440$

[2] Saharan, B.S., Grewal, A., Kumar, P. 2014. Biotechnological production of polyhydroxyalkanoates: A review on trends and latest developments. Chinese Journal of Biology, vol. 2014, Article ID: 802984, 18pages, DOI: $10.1155 / 2014 / 802984$

[3] Mothes, J., Ackermann, J.-U., Babel, W. 2004. Mole Fraction Control of Poly([R]-3-hydroxybutyrate-co-3-hydroxyvalerate) (PHB/HV) Synthesized by Paracoccus denitrificans. Engineering in Life Sciences, 4 (3), 247-251.

[4] Kalaiyezhini, D. and Ramachandran, K.B. 2014. Biosynthesis of Poly-3-Hydroxybutyrate (PHB) from Glycerol by Paracoccus denitrificans in a Batch Bioreactor: Effect of Process Variables. Preparative Biochemistry and Biotechnology, 45(1), 69-83.

[5] Ueda, S., Matsumoto, S., Takagi, A., Yamane, T. 1992. Synthesis of Poly(3-Hydroxybutyrate-co-3-Hydroxyvalerate) from Methanol and $n$-Amyl Alcohol by the Methylotrophic Bacteria Paracoccus denitrificans and Methylobacterium extorquens, Appl.Environ.Microbiol., 58(11), 3574-3579.

[6] Siegel, R.S. and Ollis, D. F. 1984. Kinetics of growth of the hydrogen - oxidizing bacterium Alcaligenes eutrophus (ATCC17707) in chemostat culture. Biotechnology and Bioengineering, 26(7), 764 - 770. 1984

[7] Ishizaki, A. and Tanaka, K. 1990. Batch culture of Alcaligenes eutrophus ATCC $17697^{\mathrm{T}}$ using recycled gas closed circuit culture system. J.Ferment.Bioeng., 69(3), 170-174.

[8] Sonnleitner, B., Heinzle, E., Braunegg, G., Lafferty, R.M. 1979. Formal kinetics of poly- $\beta$-hydroxybutyric acid (PHB) production in Alcaligenes eutrophus H16 and Mycoplana rubra R14 with respect to the dissolved oxygen tension in ammonium-limited batch cultures. Eur.J Appl.Microbiol.Bio technol., 7(1), 1-10.

[9] Tanaka, K., Miyawaki, K., Yamaguchi, A., Kianoush, K.D., Matsusaki, H. 2011. Cell growth and $\mathrm{P}(3 \mathrm{HB})$ accumulation from $\mathrm{CO}_{2}$ of a carbomonoxide-tolerant hydrogen-oxidizing bacterium, Ideonella sp. O-1. Appl.Microbiol.Biotechnol., 92(6), 1161-1169.

[10] Ohi, K., Matsumoto, H., Yamada, K. 1979. Cultivation and characterization of a hydrogen bacterium, Alcaligenes hydrogenophilus sp. nov. J.Ferment.Technol., 57(3), 195-20 2 .

[11] Schlesier, M. and Friedrich, B. 1981. In vivo inactivation of soluble hydrogenase of Alcaligenes eutrophus. Arch.Microbiol., 129(2), 150-153.

[12] Charles, F.B., Sebastian, L. R., Willis, L.B., Rha, C., Sinskey, A.J. 2011. Production of Poly(3-Hydroxybutyrate-co-3-Hydr oxyhexanoate) from Plant Oil by Engineered Ralstonia eutropha Strains. Appl. Environ. Microbiol, 77(9), 28472854.

[13] Chen, Q., Wang, Q., Wei, G., Liang, Q., Qi, Q. 2011. Production in Escherichia coli of Poly(3-Hydroxybutyrate-c $o-3$-Hydroxyvalerate) with Differing Monomer Compositions from Unrelated Carbon Sources. Appl.Environ.Microbiol., 77(14), 4886-4893.
[14] Phithakrotchanakoon, C., Champreda, V., Aiba, S., Pootanakit, K., Tanapongpipat, S. 2013. Engineered Escherichia coli for Short-Chain-Length Medium-Chain-Length Polyhydroxyalk anoate Copolymer Biosynthesis from Glycerol and Dodecanoate. Biosci. Biotechnol. Biochem., 77(6), 1262-1268.

[15] Jeon, J.-M., Brigham, C.J., Kim, Y.-H., Kim, H.-J., Yi, D.-H., Kim, H., Rha, C., Sinskey, A.J., Yang, Y.-H. 2014. Biosynthesis of poly (3-hydroxybutyrate-co-3-hydroxyhexan oate)(P(HB-co-HHx)) from butyrate using engineered Ralstonia eutropha. Appl.Microbiol.Biotechnol., 98(12), 5461-5469.

[16] Wang, Q., Tappel, R.C., Zhu, C., Nomura, C.T. 2012. Development of a New Strategy for Production of Medium-Chain-Length Polyhydroxyalkanoates by Recombinant Escherichia coli via Inexpensive Non-Fatty Acid Feedstocks. Appl.Environ.Microbiol., 78(2), 519-527.

[17] Agnew, D.E., Stevermer, A.K., Youngquist, J.T., Pfleger, B.F. 2012. Engineering Escherichia coli for production of $\mathrm{C}_{12}-\mathrm{C}_{14}$ polyhydroxyalkanoate from glucose. Metabolic Engineering, 14(6), 705-713.

[18] Fukui, T., Mukoyama, M., Orita, I., Nakamura, S. 2014. Enhancement of glycerol utilization ability of Ralstonia eutropha H16 for production of polyhydroxyalkanoates. Appl.Microbiol.Biotechnol,, 98(17), 7559-7568.

[19] Tappel, R.C., Pan, W., Bergey, N.S., Wang, Q., Patterson, I.L., Ozumba, O.A., Matsumoto, K., Taguchi, S., Nomura, C.T. 2014. Engineering Escherichia coli for Improved Production of Short-Chain-Length-co-Medium-Chain-Length Poly[(R)3-hydroxyalkanoate] (SCL-co-MCL PHA) Copolymers from Renewable Nonfatty Acid Feedstocks. ACS Sustainable Chem. Eng, 2(7), 1879-1887.

[20] Yang, J.E., Choi, Y.J., Lee, S.J., Kang, K.-H., Lee, H., Oh, Y.H., Lee, S.H., Park, S.J., Lee, S.Y. 2014. Metabolic engineering of Escherichia coli for biosynthesis of poly(3-hydroxybutyrate-co-3-hydroxyvalerate) from glucose. Appl.Microbiol. Biotechnol, 98(1), 95-104.

[21] Hokamura, A., Wakida, I., Miyahara, U., Tsuge, T., Shiratsuchi, H., Tanaka, K., Matsusaki, H. 2015. Biosynthesis of poly(3-hydroxybutyrate-co- 3-hydroxyalkanoates) by recombinant Escherichia coli from glucose. J.Biosci.Bioeng., 120(3), 305-310.

[22] Insomphun, C., Xie, H., Mifune, J., Kawashima, Y., Orita, I., Nakamura, S., Fukui, T. 2015. Improved artificial pathway for biosynthesis of poly(3-hydroxybutyrate-co-3-hydroxyhex anoate) with high $\mathrm{C}_{6}$-monomer composition from fructose in Ralstonia eutropha. Metabolic Engineering, 27, 38-45.

[23] Kianoush, K. D., K., Mokhtari, Z. B., Amai, T., Tanaka, K. 2013. Microbial production of poly(hydroxybutyrate) from C1 carbon sources. Appl.Microbiol. Biotechnol, 97(4), 1407-1424.

[24] Ishizaki, A. and Tanaka, K. 1991. Production of poly- $\beta$-hydroxybutyric acid from carbon dioxide by Alcaligenes eutrophus ATCC $17697^{\mathrm{T}}$. J.Ferment.Bioeng., 71(4), 254-257.

[25] Tanaka, K., Ishizaki, A., Kanamaru, T., Kawano, T. 1995. Production of poly (D-3-hydroxybutyrate) from $\mathrm{CO}_{2}, \mathrm{H}_{2}$, and $\mathrm{CO}_{2}$ by high cell density autotrophic cultivation of Alcaligenes eutrophus. Biotechnol.Bioeng., 45(3), 268-275. 
[26] Taga, N., Tanaka, K. Ishizaki, A. 1997. Effects of rheological change by addition of carboxymethylcellulose in culture media of an air-lift fermentor on poly-D-3-hydroxybutyric acid productivity in autotrophic culture of hydrogen -oxidizing bacterium. Alcaligenes eutrophus. Biotechnol.Bio eng., 53(5), 529-533.

[27] Sugimoto, T., Tsuge, T., Tanaka, T., Ishizaki, A. 1999. Control of acetic acid concentration by $\mathrm{pH}$-stat continuous substrate feeding in heterotrophic culture phase of two-stage cultivation of Alcaligenes eutrophus for production of $\mathrm{P}(3 \mathrm{HB})$ from $\mathrm{CO}_{2}, \mathrm{H}_{2}$ and $\mathrm{O}_{2}$ under non-explosive condition. Biotechnol.Bioeng., 62(6), 625-631.

[28] Volova, T.G., Kalacheva, G.S., Altukhova, O.V. 2002. Autotrophic synthesis of polyhydroxyalkanoates by the bacteria Ralstonia eutropha in the presence of carbon monoxide. Appl.Microbiol.Biotechnol., 58(5), 675-8. 